\title{
A Theoretical Framework on the Determinants of Food Purchasing Behavior of the Elderly: A Bibliometric Review with Scientific Mapping in Web of Science
}

\author{
Khaled Alhammadi, Luna Santos-Roldán * and Luis Javier Cabeza-Ramírez \\ Department of Statistics, Econometrics, Operations Research, Business Organization and Apllied Economics, \\ Faculty of Law, Business and Economic Sciences, University of Cordoba, 14071 Cordoba, Spain; \\ ep2alalk@uco.es (K.A.); r62caral@uco.es (L.J.C.-R.) \\ * Correspondence: luna.santos@uco.es; Tel.: +34-957-212-688
}

\section{check for}

updates

Citation: Alhammadi, K.;

Santos-Roldán, L.; Cabeza-Ramírez,

L.J. A Theoretical Framework on the Determinants of Food Purchasing

Behavior of the Elderly: A

Bibliometric Review with Scientific Mapping in Web of Science. Foods 2021, 10, 688. https://doi.org/ 10.3390 / foods 10030688

Academic Editors: Laura Laguna and Amparo Tarrega

Received: 14 February 2021

Accepted: 17 March 2021

Published: 23 March 2021

Publisher's Note: MDPI stays neutral with regard to jurisdictional claims in published maps and institutional affiliations.

Copyright: (c) 2021 by the authors. Licensee MDPI, Basel, Switzerland. This article is an open access article distributed under the terms and conditions of the Creative Commons Attribution (CC BY) license (https:// creativecommons.org/licenses/by/ $4.0 /)$.
Abstract: The past few years have seen significant demographic changes in most regions, including an increased elderly population. Subsequently, elderly citizens comprise an important market segment of consumers, with the food industry one of the most affected areas in this context. However, food market managers previously believed that elderly consumers' needs were stereotyped in nature. The lack of focus on this sector, therefore, left elderly consumers as an untapped market, without realizing the financial independence of this segment regarding their nutrition. This research will attempt to provide the key determinant factors on elderly consumers' behavior related to food. For that purpose, a complete literature review of more than 123 papers regarding these concepts has been carried out. Once analyzed, we highlight the common insights to give clear guidance for supermarket managers and food manufacturers to have a better knowledge of the reasons behind elderly people's food acquisitions.

Keywords: elderly; older consumer; purchasing behavior; buying behavior; good purchases; consumer behavior

\section{Introduction}

Age is one of the most critical factors that influences or affects consumer behavior [1] because it determines the way of life of an individual. For elderly consumers, the agerelated changes drive their specific choices of products and services, which tend to be different from younger adults, and, therefore, have major significance in consumer behavior and marketing [2]. As Drolet et al. [3] stated in their research, the influence of aging on consumers and their shopping experiences and purchasing decision-making is generally complicated, since it involves various behaviors and mental processes for different aging individuals. In this regard, based on the literature, some of the mental processes related to age that play a key role in influencing consumer behavior include factors of cognition, sensory functioning, motivation, and affect. Therefore, it is of great importance for marketers to use different approaches to identify the specific needs and demands of the aging population to achieve positive consumer behavior.

It is understandable that marketers cannot expect people of all ages, whether they are 20 or 70 years, to have the same desires and needs for products and services. In fact, people's habits evolve with age and time, resulting in changing needs for products and services. This is why age is one of the key factors marketers must look at when considering consumer behavior analysis [4-6]. The present work aims to advance the understanding of the research hitherto carried out on the purchasing and consumption habits of the elderly. To meet this objective, we prepared a synthesis and a systematic review of the literature [7], based on science maps [8,9], in order to highlight the aspects identified by authors who have studied this theme. Additionally, we explore the main research topics 
hitherto discussed, and propose a comprehensive theoretical framework based on previous literature. This research continues the path started among others by Yoon et al. [10], Host et al. [11], and Zniva and Weitzl [12] in an effort to group and consolidate the accumulated knowledge.

\subsection{Elderly Consumers and Their Importance}

When elderly consumers are discussed, it is important to note that over the lifespan of an individual, changes tend to occur in respect of their choices and actions. Without addressing the needs of this particular segment of consumers, it can be said that it represents a loss for businesses, as they miss out on targeting a significant percentage of the population as customers [13].

In addition, one of the key factors that make elderly consumers an important sector to focus on is that there has been a significant change in demographics over time. It is known that thanks to improved overall living standards and health conditions of people, along with greater advances in healthcare systems, longevity has increased and older people live longer. This, therefore, suggests that this particular consumer segment (elderly consumers) is continuously growing, and hence becomes a more important segment to address by marketers [14-16].

The importance of elderly consumers also significantly lies with their changing food habits and patterns, which in turn influence their purchasing decisions. The food consumption habits of consumers hold major significance among marketers, supermarkets, and retailers, as the sale of such products has a major influence and impact on businesses. Hence, if food habits change with age, it becomes important to highlight such changes in elderly consumers so that marketers can accordingly offer them their preferred products $[17,18]$. In this regard, the factor of heterogeneity holds another major significance, in that elderly consumers are important for marketers and retailers to consider, analyze and target as a separate consumer group [12,19]. Consumer behavior needs to be studied from the first moment the consumer is faced with a series of decisions to be made. These vary according to the type of product or purchase situation which defines their behavior. Elderly consumers have to face a wide variety of decisions when selecting a product in the market and they depend on their available resources (time, money, and knowledge).

\subsection{Challenges of Elderly and Food Purchase}

The current COVID-19 pandemic has not only caused global concerns on health issues of individuals, it has also changed the behavior of consumers, mainly because going out and shopping normally is now considered a threat to the lives of people due to the threat of the virus. Examples of changed behaviors include stocking up of essential items at home, especially in times of lockdown when going out is prohibited, owing to the need for social distancing. Unlike previous times, new products have been added to the shopping list as essential items, such as sanitizers, masks, gloves, and other protective gear, for virus protection purposes [20].

This situation represents a particular challenge for older people. Because of lockdowns and layoffs in companies to manage business losses, older people are mostly being affected, losing their jobs, experiencing major disruptions in their normal service activities, and losing their retirement savings. On the other hand, their health vulnerabilities are on the rise, along with other associated issues such as depression and anxiety driven by suffering from the disease or being in a state of panic and threat [21]. Furthermore, as they are facing challenges with their earning and savings, it also has an impact on how much they can spend on their purchases.

Thus, there is an overall change in the traditional ways and habits of shopping styles and purchases. Online purchases have increased drastically during the COVID-19 pandemic $t$, which reflects how technology is taking over. Customers are increasingly considering online shopping options instead of physically visiting the stores [22]. Due to the technological advances and increased involvement of information and communications 
technology, ICT is driving the advanced designs of supermarkets and their services, and elderly consumers are experiencing more difficulties shopping in the supermarkets. Additionally, the use of ICT, lack of proper signage, and lack of effective customer support is further reducing the motivation levels of the elderly consumers to consider supermarkets for shopping. Although they are trying to learn quickly and use technology to avoid visiting stores, they do not feel comfortable with the Internet and online shopping features. On the other hand, there is the possibility that the new habits that people are adopting could become habitual habits in the future, which could mean that older consumers will gradually adopt new experiences and shopping options [23].

\section{Materials and Methods}

In accordance with the objectives proposed in this work, two methodological approaches were combined. First, we used the PRISMA protocol [7], a proven procedure in the field of systematic literature reviews and meta-analyses that provided transparency and replicability to the review [24]. Thus, we gathered a representative set of documents related to the behavior of buying and choosing food in older people. Next, we applied scientific mapping techniques through co-word analysis [25,26], which allowed us to approach the intellectual structure of previously selected documents $[27,28]$. Both techniques have been used in previous work on the elderly $[29,30]$.

\subsection{Systematic Review of the Literature}

The PRISMA protocol integrates a series of successive stages that allow organizing the selection criteria used and reaching the relevant knowledge in a given field of study [7]. Figure 1 summarizes the whole procedure:

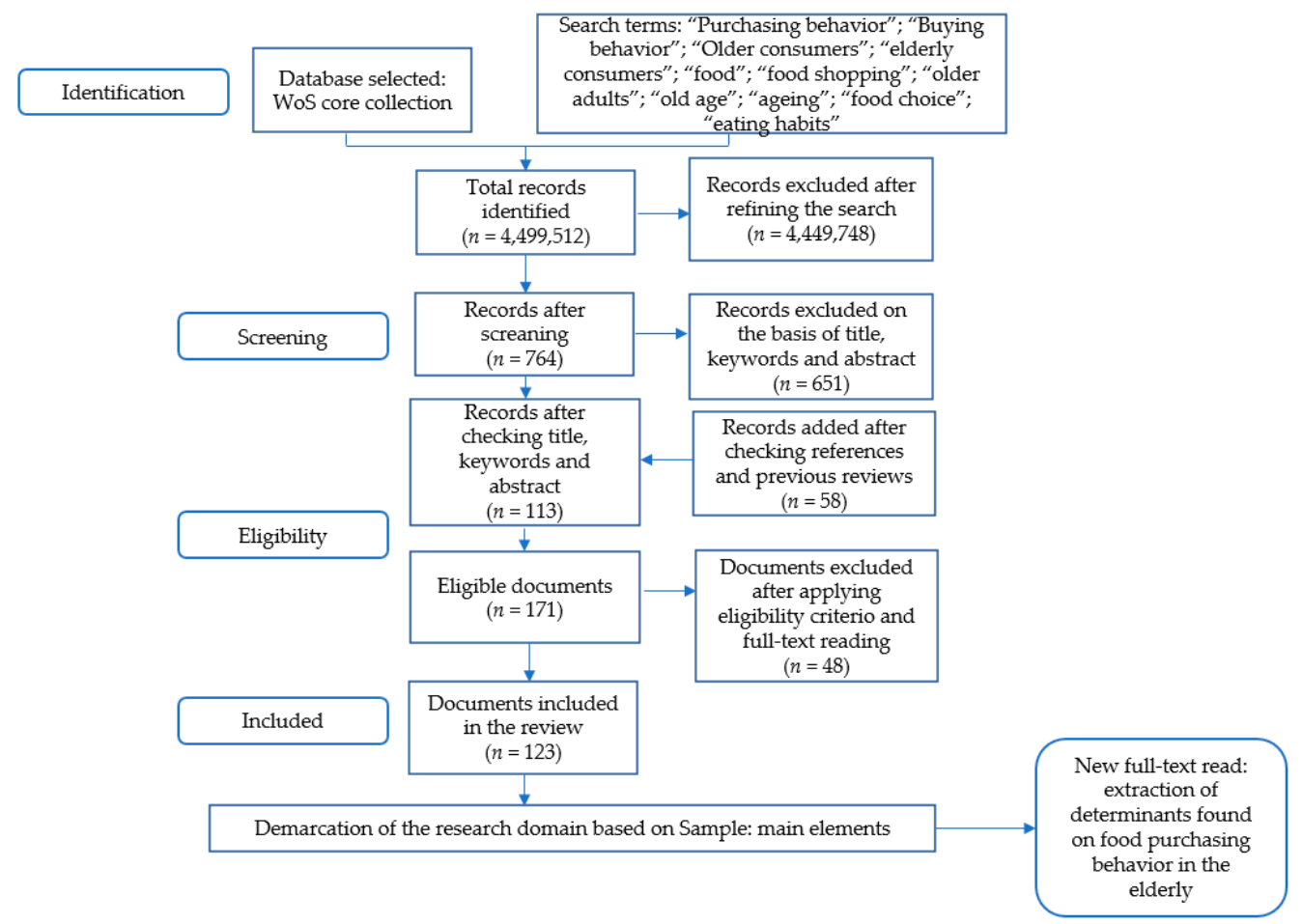

Figure 1. Flow diagram adapted according to the PRISMA protocol.

The identification included the choice of the information source. To this effect, we opted for the use of the Web of Science (WoS) Core Collection, since it ensured that unique patterns of document classification according to research areas were used; in addition, it had a sufficient volume of documents, scientific quality, and debugging [31]. The search terms were selected in line with previous research in the field of behavioral studies in the 
elderly [10-12]. The temporal coverage was not limited, nor the documentary typology, which allowed the inclusion of articles from conferences and other sources such as books or book chapters that may be of interest in the analysis of such a specific research domain. The initial search was screened and refined using the WoS "Marked list" function, applying multiple combinations with the selected keywords and the "Refine Results" option. In the initial searches, all records that could not be discarded without reading the full text were kept, and then the references contained in the selected studies were screened and compared with documents included in previous reviews [10-12].

There were three eligibility criteria. In the first place, the theme had to directly address consumer behavior or choice in older people. Second, the document had to address food consumption, even if it was part of a larger investigation or at least indirectly. Thirdly, it must be possible to retrieve the full text. For that purpose, a first reading was carried out, discarding those documents without a specific theme or methodology or those that did not provide research data, objectives, or results clearly.

The document search process began in November 2020 and was updated until February 2021, adding new records as a result of new publications. The second reading of documents was carried out and the determinants found in the sample were synthesized, from which a summary was extracted with the objectives and variables reported in the 123 documents constituting the review.

\subsection{Systematic Map: Co-Word Analysis}

The so-called science maps are spatial representations that help to visualize the relations that arise between documents, in other words, they show links between authors, bibliographic references, journals, disciplines, and predominately words [25-27]. In relation to the research objective, a network analysis was proposed that delved into the content of the documents through the co-occurrence of keywords. This methodology is especially suitable if the intention is to advance the intellectual structure of a specific part of a domain or research field [26,28]. As pointed out by Choi et al. [32], the keywords indexed in documents and those contained in titles and abstracts are essential for the identification of significant topics within a specific research area.

The visual representation of this type of map is usually done with bibliometric software [19]. In this research, we used VOSviewer [9] and SciMAT [8]. The first tool was used to offer a broad vision of the research domain focused on the determinants of food buying behavior in older people and, the second, to illustrate the "motor", "basic", "emerging", "developed", or "isolated" themes within the domain [33]. The combination of both instruments increased the advantages and offered new possibilities for global interpretation [34-36].

VOSviewer stands out for its graphic power; it is positioned as a particularly suitable instrument [37] to show the complete domain of research. With this tool, the centrality of a word (node) determines its relative position in the network. The software calculates the centrality and strength of all the words; the greater the weight is, the larger the node or word size is. Links between nodes represent the number of times words appear together, and the strength of the link is illustrated by its thickness. For its part, Scimat incorporates more options related to the scientific mapping workflow [35,37]; for example, it is easier to identify the documents that are generating specific thematic networks and are highlighted within the set. Table 1 shows the data related to the configuration used with the two tools. In VOSviewer, a minimum frequency of occurrences of 2 was determined, since it was intended to broadly show the largest possible number of thematic networks. A thesaurus file was used to debug and group synonymous terms or the singular and plural of certain words (for example: aged, age; behaviors, behavior, etc.). In the case of Scimat, we proceeded in the same way, using its grouping and debugging tools. 
Table 1. Software configuration.

\begin{tabular}{|c|c|c|c|}
\hline \multicolumn{2}{|c|}{ VoSviewer V.1.6.16 } & \multicolumn{2}{|c|}{ Scimat V.1.1.04 } \\
\hline Item & Characteristic/Value & Item & Characteristic/Value \\
\hline Type analysis & Co-occurrence & Select periods & Period (1973-2021) \\
\hline Unit & All Keywords & Unit & Author's Words \\
\hline $\begin{array}{l}\text { Counting } \\
\text { method }\end{array}$ & Full counting & Data reduction & Frequency reduction $=2$ \\
\hline $\begin{array}{l}\text { Normalization } \\
\text { Method }\end{array}$ & Association Strength & Kind of matrix & Co-occurrence \\
\hline Layout & Attraction $=2 /$ Repulsion $=0$ & $\begin{array}{l}\text { Network } \\
\text { reduction }\end{array}$ & Minimum value $=1$ \\
\hline Clustering & $\begin{array}{l}\text { Resolution }=1.00 / \mathrm{Min} \\
\quad \text { Cluster size }=10\end{array}$ & $\begin{array}{l}\text { Normalization } \\
\text { Method }\end{array}$ & Equivalence index \\
\hline $\begin{array}{l}\text { Visualization } \\
\text { Scale }\end{array}$ & Network and overlay = 1.27 & $\begin{array}{l}\text { Cluster } \\
\text { Algorithm }\end{array}$ & $\begin{array}{c}\text { Simple centers (Max } \\
\text { network = 12; } \operatorname{Min}=3 \text { ) }\end{array}$ \\
\hline Weights & Occurrences & Mapper & core mapper \\
\hline $\begin{array}{l}\text { Labels size } \\
\text { variation }\end{array}$ & $\begin{array}{l}\text { Min. Strength }=0 / \text { Max. } \\
\text { Lines }=500\end{array}$ & $\begin{array}{l}\text { Quality } \\
\text { measures }\end{array}$ & all \\
\hline $\begin{array}{c}\text { Minimum } \\
\text { numbers of } \\
\text { occurrences of a } \\
\text { keyword }\end{array}$ & 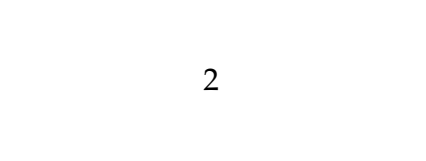 & $\begin{array}{l}\text { Longitudinal } \\
\text { map }\end{array}$ & Equivalence index \\
\hline
\end{tabular}

On the other hand, Scimat represents the themes (keywords) in two-dimensional diagrams where the " $x$ " axis shows the centrality and the " $y$ " axis shows the density of the thematic groupings. Centrality establishes the degree of interaction of a topic or word with others, in other words, its importance for the development of the domain. Density reflects the internal strength of the subject with respect to others, that is, the ability to maintain and develop over time. As a result, a diagram composed of four quadrants was generated: (a) Motor themes, with high centrality and density; (b) Basic themes, with high centrality and low density; (c) Emerging or declining themes, with low centrality and density, and (d) Developed and isolated themes, with low centrality and high density. For the creation of the networks, the algorithm of the simple centers and the equivalence index were applied. More details on the configuration and application of the software can be found in $[8,27,33]$.

\section{Results}

The sample consisted of a total of 123 documents [4-6,10,13-19,38-149] whose analysis period included works published and indexed in the database in the interval between 1973 [125] and February 2021.

\subsection{Description of the Sample Documents}

The first documents dealt with the mobility and transportation difficulties faced by the elderly to satisfy basic food needs [125], their satisfactory and unsatisfactory experiences with purchased products [99], and attitudes and preferences regarding purchased foods [118]. On this basis, progress was made towards greater complexity in the topics and variables used to obtain a better understanding of the results. For example, the most recent documents addressed the influence of the senses on eating behavior [6], food insecurity, loneliness, and social support among the elderly [44], or the consumer's assessment of specific foods [4]. Figure 2 shows the document typology and the indexing categories in WoS, taking into account that the same document can be indexed in several categories or typologies simultaneously. 


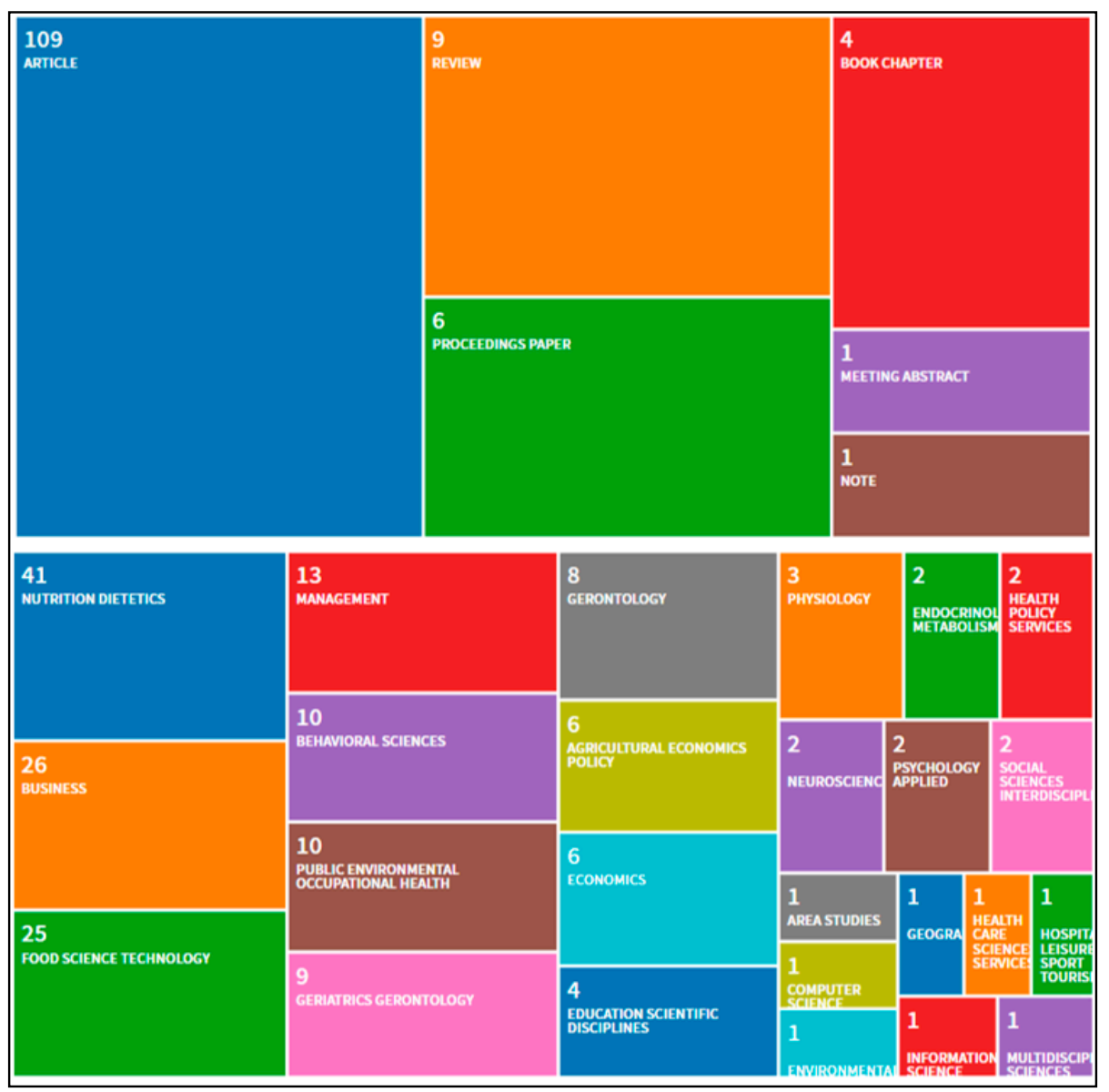

Figure 2. Documentary typology and predominant indexing categories.

The 123 documents mainly included articles, quantitative and qualitative works (obtained from samples of different sizes, local, regional and national, of different age groups, usually from 50 years), descriptive statistics and rigorous tests, segmentations [138], and general reviews $[16,74,148]$. As expected, the main indexing categories were aligned with the main theme of this review, such that documents cataloged as nutrition and dietetics [64], business [10] and food, science and technology [89] stood out.

\subsection{Global Visualization of Accumulated Research Using VoSviewer}

The keyword network with the criteria established in the methodology section with a minimum of two occurrences was composed of 170 words. The most representative keywords generated different clusters. Those with the strongest links and number of occurrences designated the grouping by assigning a label. Table 2 shows the summary with the main groupings and Figure 3 shows their visualization, as well as the level of saturation.

The first thematic grouping was characterized by grouping themes related to the motivation of the elderly consumer $[79,95,106,108]$, and the different segments into which these themes could be grouped $[84,138,140]$. The second grouping included papers that addressed characteristic issues such as quality of life or the nutritional status of older people $[19,69]$. The third cluster included topics related to the health of the individual and the quality of the diet [50,120]. The fourth grouping mainly addressed patterns of behavior in the purchase of food [14,68,72,126], as well as risks [116] or diseases associated with their eating $[41,106,137]$. The fifth grouping delved into generational differences related to consumption $[111,146,147]$. The sixth cluster stood out for including the different ways of understanding consumption orientation according to the age groups found in the elderly $[75,95,97,123]$, as well as other influential variables such as the available 
information $[53,90,127]$. The seventh grouping was very varied, it included topics aligned with the different determinants that could be found to understand the multiple patterns of consumption $[43,48,55,65,68,80,112,122,136]$. Finally, the last grouping included topics related to additional variables such as attitudes $[103,118]$, knowledge $[16,139]$, or heterogeneity $[17,138,140]$.

Table 2. Thematic cluster detected in global research.

\begin{tabular}{|c|c|c|}
\hline Cluster/Color/Label & $\mathbf{N}^{\circ}$ Keywords & First Five Keywords (Links, Total Link Strength, Occurrences) \\
\hline $\mathrm{C} 1 / \mathrm{red} /$ Older Consumer & 36 & $\begin{array}{l}\text { Older consumers }(108,255,37) ; \text { Food }(76,139,17) \text {; Perception }(73, \\
122,15) \text {; Segmentation }(65,96,11) \text {; Motivation }(57,91,11)\end{array}$ \\
\hline C2/Green/Elderly & 25 & $\begin{array}{c}\text { Elderly }(94,188,23) \text {; Protein }(56,87,10) \text { Quality of life }(59,84,9) ; \\
\text { Malnutrition }(42,70,8) \text {; Nutritional Status }(32,42,5) \text {; Energy }(26,29 \text {, } \\
4)\end{array}$ \\
\hline C3/Blue/Health & 24 & $\begin{array}{l}\text { Health }(105,229,27) \text {; Nutrition }(103,227,26) \text {; Diet Quality }(40,56 \text {, } \\
\text { 7), Older adults }(37,44,7) \text {; Community Dwelling older adults (40, } \\
55,5)\end{array}$ \\
\hline C4/Yellow/Patterns & 22 & $\begin{array}{c}\text { Patterns }(57,81,10) \text {; People }(52,84,9) \text {; Risk }(39,58,7) \text { Food } \\
\text { Shopping }(32,37,6) \text {; Aged Related Diseases }(33,39,4)\end{array}$ \\
\hline C5/Purple/Consumption & 21 & $\begin{array}{c}\text { Consumption }(88,185,26) \text {; Food Choice }(40,70,10) \text {; Diet }(63,103 \text {, } \\
\text { 12); Baby Boomers }(39,58,7) \text {; Survey }(32,46,5)\end{array}$ \\
\hline C6/LightBlue/Older adult & 17 & $\begin{array}{l}\text { Older adult }(89,166,21) \text {; Age Differences }(82,147,20) \text {; Choice } \\
\text { Orientation }(75,132,18) ; \text { Aging }(58,83,13) \text {; Information }(25,35,5) \\
\text { Determinants }(57,101,11) \text {; Consumer Behavior }(27,33,5) ; \text { Food }\end{array}$ \\
\hline C7/Orange/Determinants & 13 & 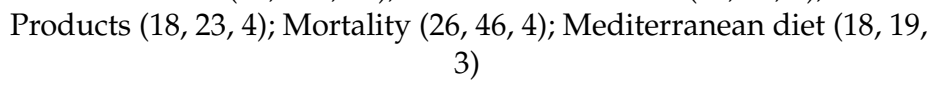 \\
\hline C8/Brown/Behavior & 12 & $\begin{array}{l}\text { Behavior }(62,11,16) \text {; Attitudes }(58,103,13) \text {; Knowledge }(42,54,6) \text {; } \\
\text { Functional Food }(34,53,6) \text {; Heterogeneity }(21,27,3)\end{array}$ \\
\hline
\end{tabular}

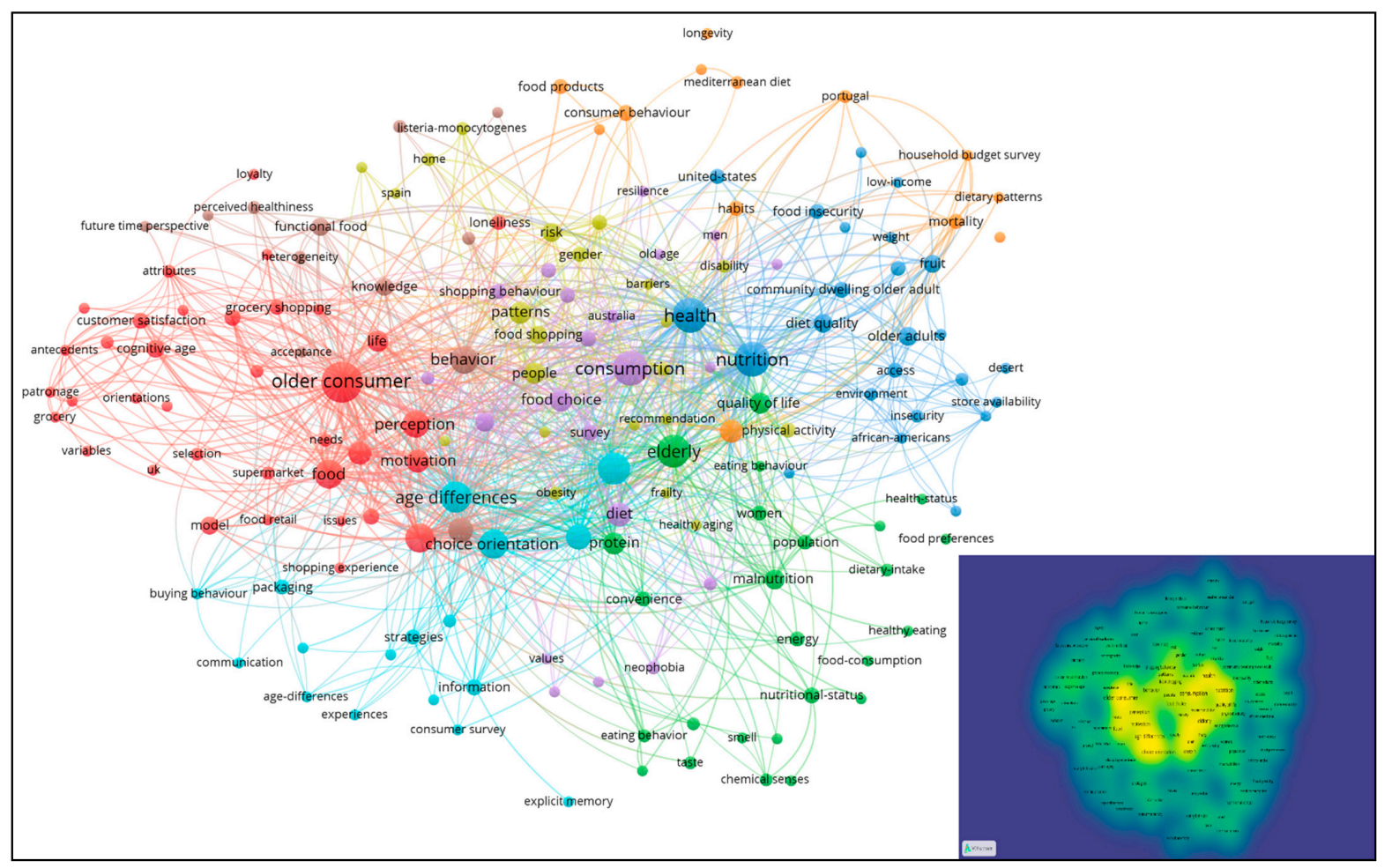

Figure 3. Map of thematic clusters detected and density visualization.

As a whole, the research domain represented through the sample of documents did not reflect signs of saturation (Figure 3, bottom); however, it included a multitude of 
overlapping topics that became intertwined and progressively hindered a specific understanding.

\subsection{Conceptual Field Evolution Using Scimat}

The documents indexed a total of 678 terms or keywords that were reduced to 459 keywords by grouping singular and plural, or synonymous terms, as indicated in the methodology section. After executing the Scimat scientific mapping software with the established configuration (Table 1), 14 strategic topics were obtained related to the research domain on food purchases and consumption habits in elderly people. Table 3 lists the centrality and density of each of the clusters, as well as the main documents linked to each cluster. The topics with greater centrality and density were configured as engines of the research domain. Among them were "Countries", "Antecedents", "Meat-consumption", "Population", "Age-Differences", and "People". As basic and cross-cutting themes, "Determinants" and "Senior-Marketing" appeared. Thirdly, four emerging or declining themes emerged: "Accessibility", "Loneliness", "Food-Products", and "Aging-population" and, finally, two rapidly developing or isolated themes: "Supermarket" and "Odor".

Table 3. Thematic cluster and core documents detected by Scimat.

\begin{tabular}{|c|c|c|c|c|c|c|}
\hline Themes & $\mathbf{Q}$ & Centrality & $\begin{array}{l}\text { Centrality } \\
\text { Range }\end{array}$ & Density & $\begin{array}{l}\text { Density } \\
\text { Range }\end{array}$ & Core Documents (Highly Cited) \\
\hline Countries & 1 & 279.74 & 1 & 41.19 & 0.86 & $\begin{array}{c}{[4,5,14-} \\
16,18,38,39,41,42,45,47,48,50-52,55- \\
60,62,65,68,69,72-75,77-81,83- \\
85,91-93,97,100,104-106,109,111- \\
116,119-123,130,132,134,137- \\
139,142,143,146,147,149]\end{array}$ \\
\hline Antecedents & 1 & 132.68 & 0.64 & 73.88 & 1 & {$[13,17,18,39,40,96,108,133]$} \\
\hline $\begin{array}{l}\text { Meat- } \\
\text { consumption }\end{array}$ & 1 & 131.61 & 0.57 & 59.02 & 0.93 & $\begin{array}{c}{[4,19,41,43,48,60,65,70,77,103,112} \\
139,140]\end{array}$ \\
\hline Population & 1 & 148.47 & 0.79 & 27.26 & 0.64 & $\begin{array}{c}{[19,41,49,52,55,56,105,112,147]} \\
{[10,13,39,46,50,61,62,66,69,71,77,87,}\end{array}$ \\
\hline Age-differences & 1 & 164.8 & 0.86 & 23.14 & 0.57 & $\begin{array}{c}88,107,108,110,111,116,127,129,130 \\
139-141]\end{array}$ \\
\hline People & 1 & 140.05 & 0.71 & 21.99 & 0.5 & $\begin{array}{c}{[19,46,49,67,77,84,93,134,137]} \\
{[5,14,19,43,47,51,59,60,65,79,91,103,}\end{array}$ \\
\hline Determinants & 2 & 167.87 & 0.93 & 19.1 & 0.43 & $\begin{array}{c}106-108,113,115,119,120,130,135,138, \\
146,147,149]\end{array}$ \\
\hline $\begin{array}{l}\text { Senior- } \\
\text { marketing }\end{array}$ & 2 & 131.34 & 0.5 & 15.13 & 0.21 & $\begin{array}{c}{[16,75,85,92,104,107,116,117,123} \\
139]\end{array}$ \\
\hline Accessibility & 3 & 56.75 & 0.21 & 18.29 & 0.36 & {$[81,104,105,124]$} \\
\hline Loneliness & 3 & 124.73 & 0.36 & 18.02 & 0.29 & {$[5,17,44,55,56,58,61,67,108,114,138]$} \\
\hline Food-products & 3 & 44.11 & 0.14 & 13.91 & 0.14 & {$[57,101,133,149]$} \\
\hline $\begin{array}{l}\text { Aging- } \\
\text { population }\end{array}$ & 3 & 107.29 & 0.29 & 13.89 & 0.07 & {$[6,13,62,110,121,132,134,143]$} \\
\hline Supermarket & 4 & 130.51 & 0.43 & 32.02 & 0.71 & {$[17,18,63,104,109,115]$} \\
\hline Odor & 4 & 31.83 & 0.07 & 33.33 & 0.79 & {$[89,122,129]$} \\
\hline
\end{tabular}

Due to the fact that some of the labels assigned to the different groupings could be too generic, their interpretation was extended to the set of the most representative terms contained in each one of them, as well as to the number of documents in which they appeared, as shown in the (Figure 4).

The motor themes located in the first quadrant (Q1) were mainly composed of groupings that included attributes and characteristics that were best adapted to the elderly that were shown to be decisive in understanding purchasing and consumption behavior [10-12,138]. It was fundamentally about a person's individual elements, including their habits and customs, as well as the analyses carried out in different countries and 
geographical contexts $[56,57,108]$. Among the most prominent were common topics such as "Nutrition" [41,90,148], "Health" [41,93,112], "Disease" [41,106,137], "PersonalSatisfaction" [46,92,99], "Orientations" [88], "Gender Differences" [49,110], "Quality of Life" [67,69,120], and "Age differences" [53]. These groups made substantial contributions to the development of the domain since its inception and were still in full force.

The basic and cross-cutting topics were positioned in the second quadrant (Q2) and corresponded to two main topics- "Determinants" [48,55,65,68,80,112,122,136] and "Senior Marketing" [82,107,132]. Among the most prominent groups were those focused on the determinants of consumption and eating patterns [14,72,126], which included purchasing habits and behaviors and actions carried out in the field of marketing specifically aimed at the different segments that made up the group of elderly people. These themes extended indirectly or crosswise through the rest of the groupings detected (Q1, Q3, Q4), complementing the motor themes of the domain, and were fundamental in providing a better understanding of the rest of the groupings generated.

The emerging or declining topics located in the third quadrant (Q3) dealt mainly with attributes linked to establishments [81], types of stores [38], retail stores [39,111], availability $[104,124]$, choice $[40,108]$, environment $[17,94]$ or source of satisfaction and dissatisfaction in the elderly clients $[46,92,99]$.

Finally, quadrant four collected highly developed or isolated themes and mainly integrated groupings related to the senses $[62,89,122,129]$ and department stores $[17,18,63,104,109,115]$.

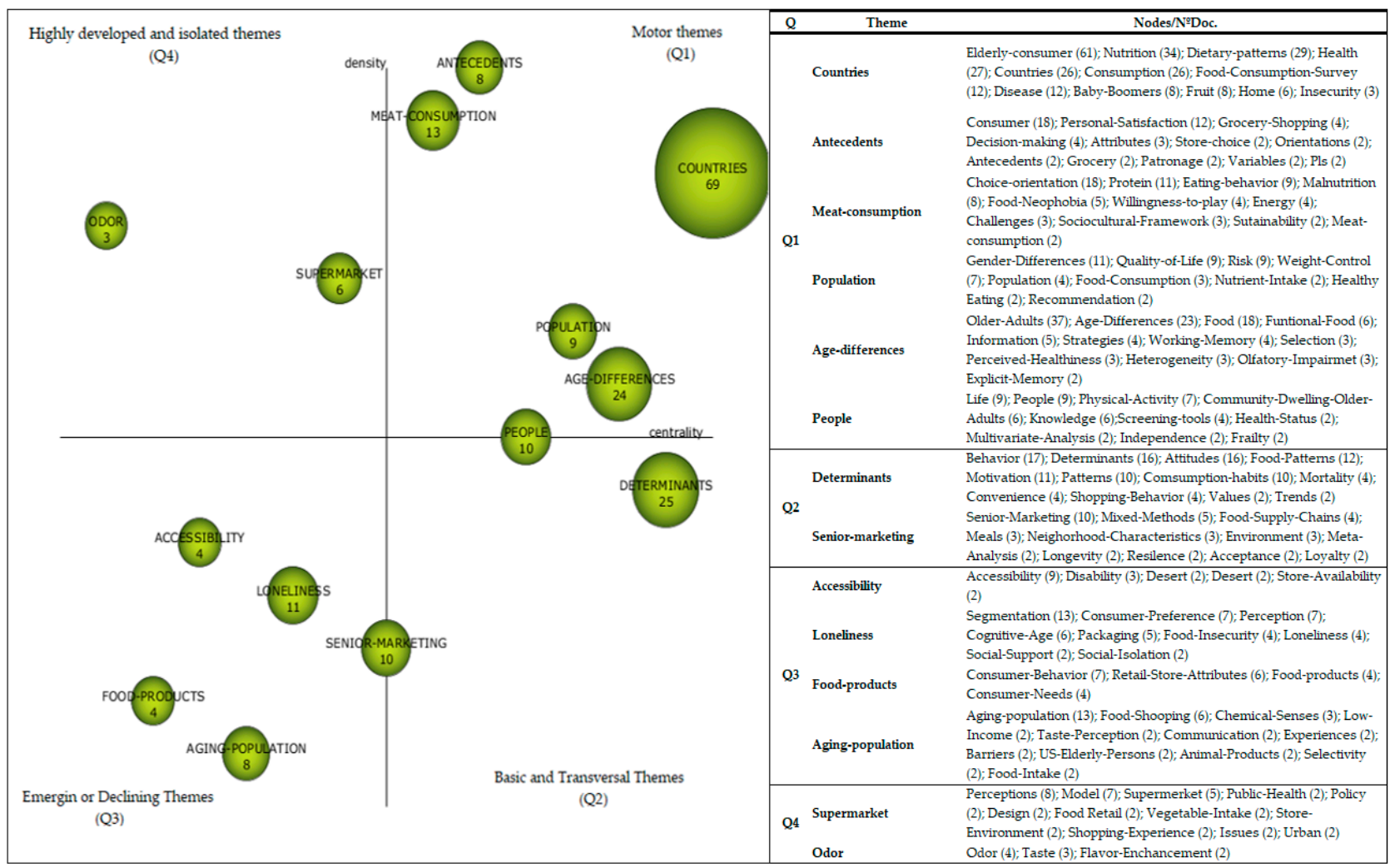

Figure 4. Matrix diagram depicting the performance of the research themes by the number of documents.

\subsection{A Integrative Theoretical Framework through Thematic Analysis}

Once the topics through which the set of representative documents of the research domain were configured, a review of the literature and a full-text reading of the set were carried out. Subsequently, a multilevel perspective was applied [150] based on the progress reported in previous reviews [10-12]. In this way, three levels were established. The first level, called the person level, collected the individual characteristics of the elderly person, 
including their individual traits, age, generation or cohort, goals, motivations, and general psychography $[10,138]$. The second level, called the intermediate level, was based on the person-task adjustments, which linked the characteristics with the changes that the individual had undergone relative to the passage of time; for example, changes in health, nutrition, or finances. The third level, called product, linked the food product with the characteristics and attributes of the establishments where purchases were made and which were a source of satisfaction and dissatisfaction. Finally, the thematic groupings obtained with VoSviewer and Scimat were positioned according to the degree of proximity to each of the three levels, as shown in (Figure 5).

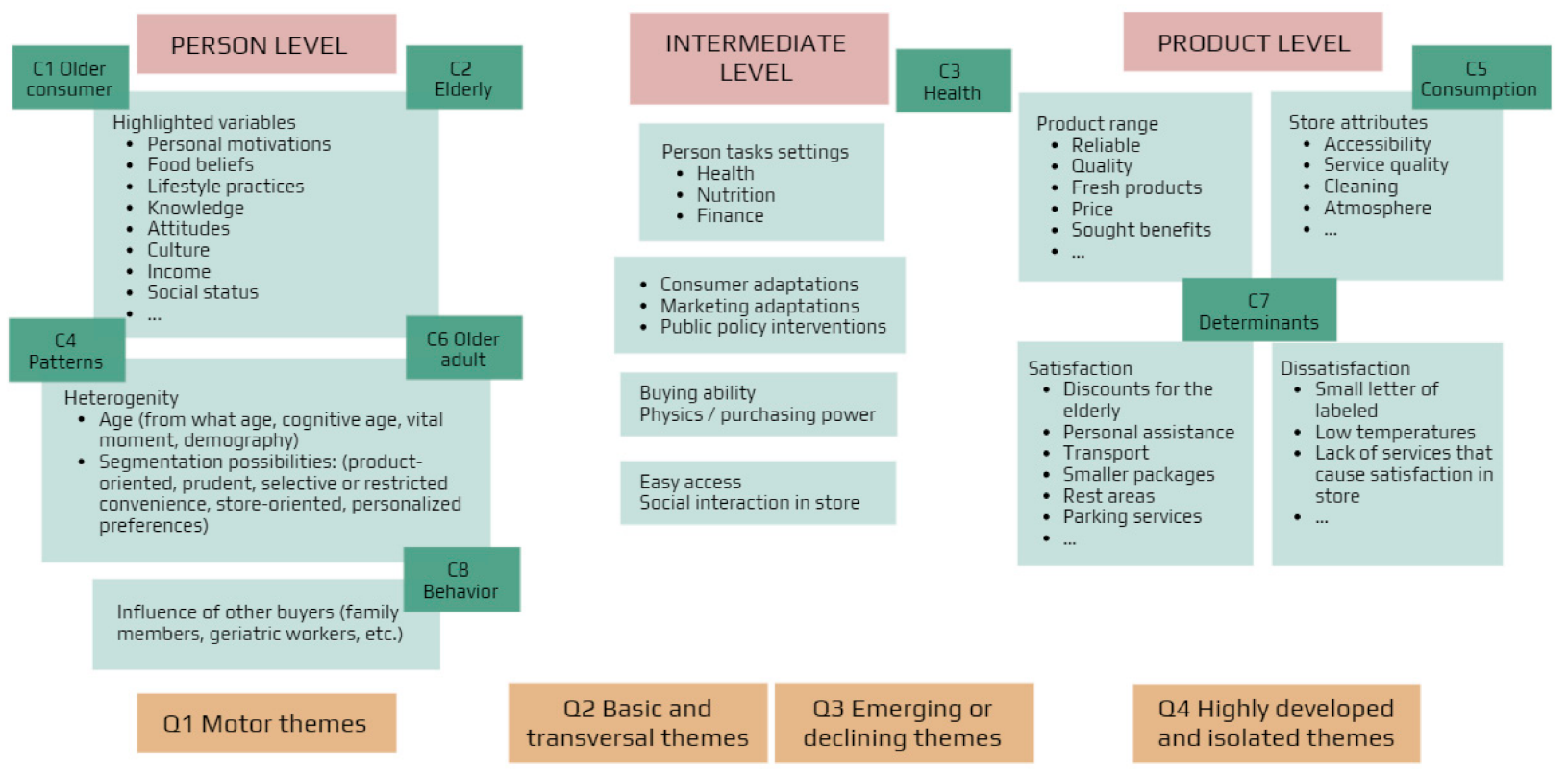

Figure 5. Theoretical framework and positioning of thematic clusters obtained with VoSviewer and Scimat.

\section{Discussion and Conclusions}

Based on the theoretical model proposed in this article and the results provided by its analysis, three different levels are shown:

First of all, the "personal level" was widely considered. To explain the behavior of the elderly consumer, we select the factors that can be considered personal and that constitute fundamental variables $[1,77,92,106,121]$. To begin with, the age and stage of the individual's life cycle influence the changes present in the structure of products and services. On the other hand, due to the growth of the elderly population and the adaptation of markets to their needs, aspects such as profession, level of education, and purchasing power are also included here, mainly $[51,52,123]$. However, age stands out as the main study variable. The concept of third age is commonly used to refer to those over 65 years old; however, there are studies that differ and mark the figure by more than 55 or even 75 years old. In this sense, the World Health Organization considers people aged 65 years or more as older people and people aged 85 years or over as very old people. Ultimately, the consensus opinion in the literature refers to the fact that the group of elderly people is not a homogeneous group and requires other more sophisticated segmentation factors.

On the other hand, both emotion and motivation are representative aspects of the non-cognitive part of human thought, which are defined by their intrinsic relation with factors associated with the practice of consumption [10]. The factor of affection could be reviewed as a more determining factor in the behavior among elderly consumers. In this regard, it could be deduced that their emotions further contribute to their personality and the perceptions which drive their preference for particular brands, products, or services and, hence, determine their choices of offering as well as shopping preferences [77,122]. 
Furthermore, cultural factors can be highlighted, understanding culture as a group of beliefs, rules, values, knowledge, attitudes, and habits established over time and shared by individuals from the same community. Other classifications corresponding to cultural factors are the subculture and social class, the latter being the common characteristics shared by individuals of the same social status.

Likewise, within this level, social factors are of paramount importance. The social groups of reference through a feeling of union, common rules, and objectives affect consumer behavior in the process of formalizing opinions $[44,105]$. The family stands out especially, as the modality with the greatest influence on the consumer due to its durability superior to the rest. Consequently, on a large number of occasions, the family is the driving force behind the purchase [14,110].

From this level, it can be inferred that, in recent years, as a consequence of an aging world population, the attention paid to elderly consumers has increased in the scientific literature. Nowadays it is recognized that changes in the number of working-age and elderly people influence consumption and savings patterns. Undoubtedly, older customers play and will play an important role in retail spending in a convulsed economic future in the aftermath of the global pandemic.

Secondly, an "intermediate level" in which the works of authors that affect the convenience of adaptation to this market segment are observed. It is true that for retailers it becomes crucial to firstly address and understand the specific needs and expectations of elderly consumers, considering them a completely different marketing segment to target $[42,55,83,117]$. However, the question nonetheless arises as to whether they really understand the elderly consumers. As could be reviewed, usually with aging, they experience a systematic decline in cognitive processing that includes memory issues and deficient executive functioning of the brain. Age effects also become visible in the speed of their information processing during mental operations skills [70,75,141].

In this regard, it could be considered that the emotions of elderly consumers further contribute to their personality and perceptions, which drive their affection for particular brands, products, or services and, hence, determine their choices of offering as well as shopping preferences $[10,66,108]$. Moreover, it could also be perceived that if a brand is able to develop suitable promotional measures such as advertising capable of initiating positive emotions in consumers, positive purchase actions can also be expected from the elderly consumers, since in their case, it is based on the affection factor rather than on cognition [79]. This means that marketers could review the role of advertising and marketing in influencing the affection of older consumers, as it affects the behavior of this type of consumer.

The benefits related to elderly consumers, however, lie in the scope which marketers have in developing new products to address the specific needs that this segment has, which are different from those of other customer segments. This implies that businesses can focus on innovations and newer developments in products to address this segment, as well as increasing profits from sales if they can rightly fulfill the needs and requirements of elderly consumers [116]. In relation to the necessary adaptation, we can indicate a deficit of studies focused on the role of elderly consumers in digital environments. When it comes to technological challenges, elderly consumers face difficulties in adapting to technological advances, including their physical challenges or lack of comfort with the use of technology because they lack confidence in their skills and abilities [132]. The elderly consumers need more assistance, which in turn becomes a barrier for them. However, at the same time, a major positive factor has been found associated with the use of technological advances by senior customer groups. Although they initially tend to have greater challenges with understanding technology and making use of it, once they are able to embrace technology and its benefits, the elderly people engage more with Internet-based activities, which provides major benefits for both the elderly consumers and the businesses marketing products to them [30]. This opens up new scope and opportunities for businesses to connect with this particular segment, understand their needs and hence offer them specific 
products and services. The benefits are also for elderly consumers, as they would then not lag behind other segments in respect of having information on various products and services, and hence, will make better purchasing decision-making.

Following this, it is highly recommended to managers from supermarkets to provide guides for using online systems, remove financial barriers, and prioritize a conversational user interface with audio, as well as developing apps focused on elderly users that are intuitive, with a clear layout, bigger letters, and customized guidance.

Thirdly and last, a "product level" is warned. A significant research gap could be realized in determining the purchase response of elderly consumers to supermarkets and the impacts of promotions of supermarkets on this market segment, considering the available sources of previous research findings. As could be obtained from the reviews, the choice of and responses to supermarkets have a significant association of people's choices of diets and lifestyles, which they look for being fulfilled with offerings made by the supermarkets $[18,133,145]$. The sales promotions of supermarkets are largely based on the displays of products on the shelves in multiple aisles and customers tend to get influenced by the information they have from the product packaging $[67,82,115]$. The shape and size of the products, the information shared on the packaging, and the packaging materials play a crucial part in promoting the products to the customers, which in turn determines their behavior [130]. Older people face difficulties in shopping from the high and low shelves where different products are arranged in a supermarket. The height of the shelves, signs and displays, size and proportions, and labeling are not effectively suitable for elderly consumers in most cases, particularly when they have long been comfortable with traditional grocery store style shopping. At the same time, there are changing consumption patterns among the elderly consumers, which, however, seem to be less addressed by the supermarkets in their marketing and promotions $[17,63]$.

In aspects to consider, we highlight the different physical needs in relation to the service and design of supermarkets, the predilection or rejection of department stores, or the desire for personal treatment by shop assistants [81,113]. Deficiencies and failures in these factors are the cause of elderly consumers abandoning a brand and losing loyalty. As den Uijl, Jager, de Graaf, Waddell, and Kremer [60] stated in their research paper, the loyalty of elderly consumers is more associated with their affection rather than their cognition. In this regard, it could be realized that affection, cognition, and customer satisfaction are the three key factors determining the loyalty of elderly consumers. When affection is considered, it represents the emotional and mental ways in which an individual interprets information, the actuation of their perception, which in turn determines their positive or negative feelings and affections for other people or objects.

In parallel, the location of the supermarket is a very important aspect, especially when it is a point to be evaluated by elderly consumers $[17,108]$. Numerous studies have concluded that both the distribution of products in the supermarket and the equipment for their transport are two of the most evaluated points [52]. Due to the physical deterioration of buyers, comfort is the main deciding factor. Within this convenience, the most relevant components are: easy entry and exit points, informed and trained sales staff, or celerity at checkout counters. From what has been mentioned, the physical environment/surroundings in supermarkets, malls, or restaurants are critical factors that can determine the level of influence on the minds of elderly customers towards driving them to a purchase. The effectiveness, comfort, and presentation of physical surroundings also determine how and why customers would choose one marketing brand over another, which is particularly true when it comes to physical shopping food experiences for customers. In order to achieve sales, therefore, managers need to focus on this factor significantly, ensuring that they offer a comfortable and safe physical surrounding to their elderly customers. Such physical surroundings are also significant in relation to the sales and promotion techniques considered by a marketer. In cases of supermarkets and hypermarkets, while the marketer can offer various discounts and offers on their products, it is also important that the physical surroundings are suitable. Unless the physical surroundings and shopping 
experience of the consumers are suitable and comfortable, discounts and offers or any promotional activities rarely would have significant impacts on the consumer.

\section{Limitations and Future Lines of Research}

The results presented here, including the theoretical framework developed from the previous literature, are not without limitations nor do they pretend to offer a single vision of reality. Our purpose is to make a small contribution to the structuring of an emerging and now booming research domain. The main limitation of this work stems from the choice of a single source for its development, the Web of Science Core Collection. Being aware that it is a controversial decision, it was made to mitigate possible errors derived from the use of bibliometric software. However, it opens the door to future analyses by combining other sources that help to complete and contrast the findings presented here. Secondly, the interpretation of a scientific map is extremely complex. Despite the detailed reading of all the included papers and the monitoring of a structured process, this study remains descriptive-qualitative and may harbor any bias unintentionally introduced by the researchers involved. Thirdly, only documents in English were reviewed; however, our work opens the door to future research that should be carried out based on the events that have occurred in recent times. The incidence of the period of isolation in the eating habits of the elderly is undoubtedly one of the greatest challenges for the future.

A more detailed analysis of the purchasing behavior of older people by different age ranges, gender, and nationality are proposed as future lines of research. Finally, this paper represents the first step of an on-going project with a variety of actions focused on the elderly. The authors are developing a survey in line with the research model including the constructs of loyalty, physical surroundings, buying behavior, and sales promotion techniques (point of purchase, advertisement, free sample, price discounts, two for one, and refunds). All these results will contribute to a proposed app to ease online shopping for this market segment and help address a very demanding need that is now fundamental to remain in business for managers of supermarkets and distributors in the food industry.

Author Contributions: Conceptualization, K.A. and L.S.-R.; methodology, L.J.C.-R.; software, L.J.C.-R.; validation, K.A. and L.S.-R.; formal analysis, K.A. and L.S.-R.; investigation, K.A., L.S.-R., and L.J.C.-R.; data curation, K.A., L.S.-R. and L.J.C.-R.; writing-original draft preparation, K.A., L.S.-R. and L.J.C.-R.; writing-review and editing, L.J.C.-R.; visualization, L.J.C.-R.; supervision, L.S.-R. and L.J.C.-R.; project administration, K.A. and L.S.-R. All authors have read and agreed to the published version of the manuscript.

Funding: This research received no external funding.

Institutional Review Board Statement: Not applicable.

Informed Consent Statement: Not applicable.

Data Availability Statement: The sample of papers and all data are available upon request to any of the authors.

Acknowledgments: Our thanks to the creators of the software used, especially Manuel Jesús Cobo (Scimat); Nees Jan van Eck and Ludo Waltman (VoSviewer).

Conflicts of Interest: The authors declare no conflict of interest.

\section{References}

1. Pratap, A. Effect of Demographic Factors on Consumer Behavior: Age, Sex, Income and Education. Available online: https: //notesmatic.com/2017/07/effect-of-demographic-factors-on-consumer-behavior-age-sex-income-and-education/ (accessed on 26 February 2021).

2. Carpenter, S.M.; Yoon, C. Chapter 17-Aging and Consumer Decision Making. In Aging and Decision Making; Hess, T.M., Strough, J., Löckenhoff, C.E., Eds.; Academic Press: San Diego, CA, USA, 2015; pp. 351-370.

3. Drolet, A.; Jiang, L.; Pour Mohammad, A.; Davis, C. The influence of aging on consumer decision-making. Consum. Psychol. Rev. 2019, 2, 3-16. 
4. Broeckhoven, I.; Verbeke, W.; Tur-Cardona, J.; Speelman, S.; Hung, Y. Consumer valuation of carbon labeled protein-enriched burgers in European older adults. Food. Qual. Prefer. 2021, 89, 11.

5. Rahman, O.; Yu, H. Key antecedents to the shopping behaviours and preferences of aging consumers a qualitative study. J. Fash. Mark. Manag. 2019, 23, 193-208.

6. Spence, C.; Youssef, J. Aging and the (Chemical) Senses: Implications for Food Behaviour amongst Elderly Consumers. Foods 2021, 10, 16.

7. Moher, D.; Shamseer, L.; Clarke, M.; Ghersi, D.; Liberati, A.; Petticrew, M.; Shekelle, P.; Stewart, L.A.; Group, P.-P. Preferred reporting items for systematic review and meta-analysis protocols (PRISMA-P) 2015 statement. Syst. Rev. $2015,4,1$.

8. Cobo, M.J.; López-Herrera, A.G.; Herrera-Viedma, E.; Herrera, F. SciMAT: A new science mapping analysis software tool. J. Am. Soc. Inf. Sci. Technol. 2012, 63, 1609-1630.

9. van Eck, N.J.; Waltman, L. Software survey: VOSviewer, a computer program for bibliometric mapping. Scientometrics 2010, 84, 523-538.

10. Yoon, C.; Cole, C.A.; Lee, M.P. Consumer decision making and aging: Current knowledge and future directions. J. Consum. Psychol. 2009, 19, 2-16.

11. Host, A.; McMahon, A.-T.; Walton, K.; Charlton, K. Factors Influencing Food Choice for Independently Living Older People-A Systematic Literature Review. J. Nutr. Gerontol. Geriatr. 2016, 35, 67-94.

12. Zniva, R.; Weitzl, W. It's not how old you are but how you are old: A review on aging and consumer behavior. Manag. Rev. $Q$. 2016, 66, 267-297.

13. Carpenter, S.M.; Yoon, C. Aging and consumer decision making. In Decision Making over the Life Span; SamanezLarkin, G.R., Ed.; Blackwell Science Publish: Oxford, UK, 2011; Volume 1235, pp. E1-E12.

14. Kim, C.O. Food choice patterns among frail older adults: The associations between social network, food choice values, and diet quality. Appetite 2016, 96, 116-121.

15. Mendonca, P.S.M.; Relvas, K.; Correa, S.R.A. Study of elderly food consumption in Brazil: Favorite foods, consumer's profile and consumption context. Rev. Cienc. Adm. 2010, 16, 529-543.

16. Thaivalappil, A.; Young, I.; Paco, C.; Jeyapalan, A.; Papadopoulos, A. Food safety and the older consumer: A systematic review and meta-regression of their knowledge and practices at home. Food Control. 2020, 107, 13.

17. Teller, C.; Gittenberger, E. Patronage behaviour of elderly supermarket shoppers—antecedents and unobserved heterogeneity. Int. Rev. Retail. Distrib. Consum. Res. 2011, 21, 483-499.

18. Yin, Y.Y.; Pei, E.; Ranchhod, A. The shopping experience of older supermarket consumers. J. Enterp. Inf. Manag. 2013, 26, 444.

19. Kim, D.; Lim, H. Association between combinations of nutritional status and quality of life and food purchasing motives among the elderly in South Korea. Health Qual. Life Outcomes 2020, 18, 9.

20. Murillo-Vargas, D. How the COVID-19 Pandemic is Influencing Consumer Behavior. 2020. Available online: https://www. contentserv.com (accessed on 26 February 2021).

21. Morrow-Howell, N.; Galucia, N.; Swinford, E. Recovering from the COVID-19 Pandemic: A Focus on Older Adults. J. Aging Soc. Policy 2020, 32, 526-535.

22. Reddy, A. Covid-19 Impact: Consumers Move more Towards Digital. 2020. Available online: https:/ /www.thehindubusinessline. com (accessed on 26 February 2021).

23. Sheth, J. Impact of Covid-19 on consumer behavior: Will the old habits return or die? J. Bus. Res. 2020, 117, $280-283$.

24. Paré, G.; Tate, M.; Johnstone, D.; Kitsiou, S. Contextualizing the twin concepts of systematicity and transparency in information systems literature reviews. Eur. J. Inf. Syst. 2016, 25, 493-508.

25. Cabeza-Ramirez, L.J.; Canizares, S.M.S.; Fuentes-Garcia, F.J. From Bibliometrics to Entrepreneurship: A Study of Studies. Rev. Esp. Doc. Cient. 2020, 43, 37.

26. Zupic, I.; Čater, T. Bibliometric Methods in Management and Organization. Organ. Res. Methods 2014, 18, 429-472.

27. Cabeza-Ramirez, L.J.; Sanchez-Canizares, S.M.; Fuentes-Garcia, F.J. Past Themes and Tracking Research Trends in Entrepreneurship: A Co-Word, Cites and Usage Count Analysis. Sustainability 2019, 11, 32.

28. Chen, X.W.; Li, J.P.; Sun, X.L.; Wu, D.S. Early identification of intellectual structure based on co-word analysis from research grants. Scientometrics 2019, 121, 349-369.

29. Camp, N.; Lewis, M.; Hunter, K.; Johnston, J.; Zecca, M.; Di Nuovo, A.; Magistro, D. Technology Used to Recognize Activities of Daily Living in Community-Dwelling Older Adults. Int. J. Environ. Res. Public Health 2021, 18, 18.

30. Jang, H.; An, J.Y. Social Network Analysis of Elders' Health Literacy and their Use of Online Health Information. Healthc. Inform. Res. 2014, 20, 216-225.

31. Harzing, A.-W.; Alakangas, S. Google Scholar, Scopus and the Web of Science: A longitudinal and cross-disciplinary comparison. Scientometrics 2016, 106, 787-804.

32. Choi, J.; Yi, S.; Lee, K.C. Analysis of keyword networks in MIS research and implications for predicting knowledge evolution. Inf. Manag. 2011, 48, 371-381.

33. Sott, M.K.; Furstenau, L.B.; Kipper, L.M.; Giraldo, F.D.; Lopez-Robles, J.R.; Cobo, M.J.; Zahid, A.; Abbasi, Q.H.; Imran, M.A. Precision Techniques and Agriculture 4.0 Technologies to Promote Sustainability in the Coffee Sector: State of the Art, Challenges and Future Trends. IEEE Access 2020, 8, 149854-149867.

34. Goksu, I. Bibliometric mapping of mobile learning. Telemat. Inform. 2021, 56, 20. 
35. Moral-Munoz, J.A.; Herrera-Viedma, E.; Santisteban-Espejo, A.; Cobo, M.J. Software tools for conducting bibliometric analysis in science: An up-to-date review. Prof. Inf. 2020, 29, 20.

36. Reichel, M.P.; Wahl, L.C.; Ellis, J.T. Research into Neospora caninum-What Have We Learnt in the Last Thirty Years? Pathogens 2020, 9, 17.

37. Gutierrez-Salcedo, M.; Martinez, M.A.; Moral-Munoz, J.A.; Herrera-Viedma, E.; Cobo, M.J. Some bibliometric procedures for analyzing and evaluating research fields. Appl. Intell. 2018, 48, 1275-1287.

38. Achon, M.; Serrano, M.; Garcia-Gonzalez, A.; Alonso-Aperte, E.; Varela-Moreiras, G. Present Food Shopping Habits in the Spanish Adult Population: A Cross-Sectional Study. Nutrients 2017, 9, 14.

39. Angell, R.; Megicks, P.; Memery, J.; Heffernan, T.; Howell, K. Understanding the older shopper: A behavioural typology. J. Retail. Consum. Serv. 2012, 19, 259-269.

40. Angell, R.J.; Megicks, P.; Memery, J.; Heffernan, T.W. Older shopper types from store image factors. J. Retail. Consum. Serv. 2014, 21, 192-202.

41. Baugreet, S.; Hamill, R.M.; Kerry, J.P.; McCarthy, S.N. Mitigating Nutrition and Health Deficiencies in Older Adults: A Role for Food Innovation? J. Food Sci. 2017, 82, 848-855.

42. Bazoche, P.; Desmonts, M.H.; Herbreteau, V.; Soler, L.G. Willingness to pay and sensory preferences for products targeting the nutritional needs of seniors: An experimental approach. Cah. Nutr. Diet. 2020, 55, 325-339.

43. Bukman, A.J.; Ronteltap, A.; Lebrun, M. Interpersonal determinants of eating behaviours in Dutch older adults living independently: A qualitative study. BMC Nutr. 2020, 6, 12.

44. Burris, M.; Kihlstrom, L.; Arce, K.S.; Prendergast, K.; Dobbins, J.; McGrath, E.; Renda, A.; Shannon, E.; Cordier, T.; Song, Y.J.; et al. Food Insecurity, Loneliness, and Social Support among Older Adults. J. Hunger Environ. Nutr. 2021, 16, $29-44$.

45. Bylok, F. Strategy of consumer behavior of the elderly on the market of consumer foods and services. Probl. Zarz. 2013, 11, 123-142.

46. Cameron, M.P.; Richardson, M.; Siameja, S. Customer dissatisfaction among older consumers: A mixed-methods approach. Ageing Soc. 2016, 36, 420-441.

47. Casini, L.; Contini, C.; Romano, C.; Scozzafava, G. Trends in food consumptions: What is happening to generation X? Br. Food J. 2015, 117, 705-718.

48. Chalermsri, C.; van Wees, S.H.; Ziaei, S.; Ekstrom, E.C.; Muangpaisan, W.; Rahman, S.M. Exploring the Experience and Determinants of the Food Choices and Eating Practices of Elderly Thai People: A Qualitative Study. Nutrients 2020, 12, 15.

49. Chang, Y.H.; Chen, R.C.Y.; Wahlqvist, M.L.; Lee, M.S. Frequent shopping by men and women increases survival in the older Taiwanese population. J. Epidemiol. Community Health 2012, 66, 6.

50. Chang, Y.H.; Hickman, H. Food Insecurity and Perceived Diet Quality among Low-Income Older Americans with Functional Limitations. J. Nutr. Educ. Behav. 2018, 50, 476-484.

51. Cheah, Y.K.; Moy, F.M.; Loh, D.A. Socio-demographic and lifestyle factors associated with nutrition label use among Malaysian adults. Br. Food J. 2015, 117, 2777-2787.

52. Clum, G.; Gustat, J.; O'Malley, K.; Begalieva, M.; Luckett, B.; Rice, J.; Johnson, C. Factors influencing consumption of fruits and vegetables in older adults in New Orleans, Louisiana. J. Nutr. Health Aging 2016, 20, 678-684.

53. Cole, C.A.; Balasubramanian, S.K. Age-differences in consumers search for information-Public-policy implications. J. Consum. Res. 1993, 20, 157-169.

54. Cole, C.A.; Houston, M.J. Encoding and media effects on consumer learning deficiencies in the elderly. J. Mark. Res. 1987, 24, 55-63.

55. Conklin, A.I.; Monsivais, P. Economic Determinants of Diet in Older Adults. In Food for the Aging Population, 2nd ed.; Raats, M.M., DeGroot, L., VanAsselt, D., Eds.; Woodhead Publ Ltd.: Cambridge, UK, 2017; pp. 145-167.

56. De Mendonca, S.; Brandao, H.; Brandao, W.; Quintino, C.A.A.; De Francisco, A.; Teixeira, E. Food preferences of middle aged and elderly subjects in a brazilian city. J. Nutr. Health Aging 2013, 17, 130-135.

57. de Morais, C.; Afonso, C.; de Almeida, M.D.V. Ageing and food consumption in Portugal: New or old paradigms? Br. Food J. 2010, 112, 511-521.

58. Dean, M.; Raats, M.M.; Grunert, K.G.; Lumbers, M.; Food Later Life, T. Factors influencing eating a varied diet in old age. Public Health Nutr. 2009, 12, 2421-2427.

59. Den Uijl, L.C.; Jager, G.; de Graaf, C.; Kremer, S. Exploring the functional mealtime associations of older adults through consumer segmentation and a means-end chain approach. Appetite 2016, 107, 613-622.

60. Den Uijl, L.C.; Jager, G.; de Graaf, C.; Waddell, J.; Kremer, S. It is not just a meal, it is an emotional experience-A segmentation of older persons based on the emotions that they associate with mealtimes. Appetite 2014, 83, 287-296.

61. Den Uijl, L.C.; Jager, G.; Zandstra, E.H.; de Graaf, C.; Kremer, S. Self-reported food-evoked emotions of younger adults, older normosmic adults, and older hyposmic adults as measured using the PrEmo2 tool and the Affect Grid. Food. Qual. Prefer. 2016, 51, 109-117.

62. Doets, E.L.; Kremer, S. The silver sensory experience-A review of senior consumers' food perception, liking and intake. Food Qual. Prefer. 2016, 48, 316-332.

63. Ejlerskov, K.; Sharp, S.J.; Stead, M.; Adamson, A.J.; White, M.; Adams, J. Socio-economic and age variations in response to supermarket-led checkout food policies: A repeated measures analysis. Int. J. Behav. Nutr. Phys. Act. 2018, 15, 9. 
64. Falk, L.W.; Bisogni, C.A.; Sobal, A. Food choice processes of older adults: A qualitative investigation. J. Nutr. Educ. 1996, 28, 257-265.

65. Ferrao, A.C.; Guine, R.P.F.; Correia, P.; Ferreira, M. Influence of Environmental and Political Determinants on Food Choices in a Sample of Portuguese Population. Curr. Nutr. Food Sci. 2020, 16, 689-697.

66. Finucane, M.L.; Mertz, C.K.; Slovic, P.; Schmidt, E.S. Task complexity and older adults' decision-making competence. Psychol. Aging 2005, 20, 71-84.

67. Ford, N.; Trott, P.; Simms, C. Exploring the impact of packaging interactions on quality of life among older consumers. J. Market. Manag. 2016, 32, 275-312.

68. Garcia, T.; Grande, I. Determinants of food expenditure patterns among older consumers. The Spanish case. Appetite 2010, 54, 62-70.

69. Giacalone, D.; Wendin, K.; Kremer, S.; Frost, M.B.; Bredie, W.L.P.; Olsson, V.; Otto, M.H.; Skjoldborg, S.; Lindberg, U.; Risvik, E. Health and quality of life in an aging population-Food and beyond. Food. Qual. Prefer. 2016, 47, 166-170.

70. Grasso, A.C.; Hung, Y.; Olthof, M.R.; Verbeke, W.; Brouwer, I.A. Older Consumers' Readiness to Accept Alternative, More Sustainable Protein Sources in the European Union. Nutrients 2019, 11, 18.

71. Gregoire, Y. The impact of aging on consumer responses: What do we know? In Advances in Consumer Research; Keller, P.A., Rook, D.W., Eds.; Assoc Consumer Research: Valdosta, GA, USA, 2003; Volume 30, pp. 19-26.

72. Hayes, D.; Finney, A. Dominant Patterns of Expenditure among Older People in the United Kingdom: Segmenting the Older Consumer Using the Living Costs and Food Survey. J. Popul. Ageing 2014, 7, 97-113.

73. Heuer, T.; Krems, C.; Moon, K.; Brombach, C.; Hoffmann, I. Food consumption of adults in Germany: Results of the German National Nutrition Survey II based on diet history interviews. Br. J. Nutr. 2015, 113, 1603-1614.

74. Holman, B.W.B.; Fowler, S.M.; Hopkins, D.L. Red meat (beef and sheep) products for an ageing population: A review. Int. J. Food Sci. Technol. 2020, 55, 919-934.

75. Host, A.; McMahon, A.T.; Walton, K.; Charlton, K. 'While we can, we will': Exploring food choice and dietary behaviour amongst independent older Australians. Nutr. Diet. 2016, 73, 463-473.

76. House, G.; Gustafson, A.W. Food purchasing behavior of the rural elderly. Gerontologist 1983, 23, 157.

77. Hung, Y.; Wijnhoven, H.A.H.; Visser, M.; Verbeke, W. Appetite and Protein Intake Strata of Older Adults in the European Union: Socio-Demographic and Health Characteristics, Diet-Related and Physical Activity Behaviours. Nutrients 2019, 11, 23.

78. Hunter, W.; Worsley, T. Understanding the older food consumer. Present day behaviours and future expectations. Appetite 2009, $52,147-154$.

79. Hwang, J. Organic food as self-presentation: The role of psychological motivation in older consumers' purchase intention of organic food. J. Retail. Consum. Serv. 2016, 28, 281-287.

80. Irz, X.; Fratiglioni, L.; Kuosmanen, N.; Mazzocchi, M.; Modugno, L.; Nocella, G.; Shakersain, B.; Traill, W.B.; Xu, W.L.; Zanello, G. Sociodemographic determinants of diet quality of the EU elderly: A comparative analysis in four countries. Public Health Nutr. 2014, 17, 1177-1189.

81. Ishikawa, M.; Yokoyama, T.; Nakaya, T.; Fukuda, Y.; Takemi, Y.; Kusama, K.; Yoshiike, N.; Nozue, M.; Yoshiba, K.; Murayama, N. Food accessibility and perceptions of shopping difficulty among elderly people living alone in Japan. J. Nutr. Health Aging 2016, 20, 904-911.

82. Jerzyk, E.; Wawrzynkiewicz, N. The Effect of a Face on Packaging from the Perspective of Marketing Communication with Older Consumers. In Hradec Economic Days; Jedlicka, P., Maresova, P., Soukal, I., Eds.; Univ Hradec Kralove: Hradec Kralove, Czech Republic, 2019; Volume 9, pp. 348-356.

83. Kendall, H.; Brennan, M.; Seal, C.; Ladha, C.; Kuznesof, S. Behind the kitchen door: A novel mixed method approach for exploring the food provisioning practices of the older consumer. Food. Qual. Prefer. 2016, 53, 105-116.

84. Kendall, H.; Kuznesof, S.; Seal, C.; Dobson, S.; Brennan, M. Domestic food safety and the older consumer: A segmentation analysis. Food. Qual. Prefer. 2013, 28, 396-406.

85. Kim, M.J.; Lee, C.K.; Kim, W.G.; Kim, J.M. Relationships between lifestyle of health and sustainability and healthy food choices for seniors. Int. J. Contemp. Hosp. Manag. 2013, 25, 558-576.

86. Koehler, J.; Leonhaeuser, I.U. Changes in food preferences during aging. Ann. Nutr. Metab. 2008, 52, 15-19.

87. Kohijoki, A.M. The effect of aging on consumer disadvantage in grocery retail services among the Finnish elderly. J. Retail. Consum. Serv. 2011, 11, 370-377.

88. Kohijoki, A.M.; Marjanen, H. The effect of age on shopping orientation choice orientation types of the ageing shoppers. J. Retail. Consum. Serv. 2013, 20, 165-172.

89. Kremer, S.; Bult, J.H.F.; Mojet, J.; Kroeze, J.H.A. Food perception with age and its relationship to pleasantness. Chem. Senses 2007, 32, 591-602.

90. Krinke, U.B. Nutrition information topic and format preferences of older adults. J. Nutr. Educ. 1990, $22,292-297$.

91. Laguna, L.; Mingioni, M.; Maitre, I.; Vanwymelbeke, V.; Pirttijarvi, T.; Artigas, M.G.; Kautola, H.; Jarvenpaa, E.; Maenpaa, T.; Tahvonen, R.; et al. Perception of difficulties encountered in eating process from european elderlies' perspective. J. Texture Stud. 2016, 47, 342-352.

92. Lee, K.H.; Mo, J. The Factors Influencing Meal Satisfaction in Older Adults: A Systematic Review and Meta-analysis. Asian Nurs. Res. 2019, 13, 169-176. 
93. Lee, K.I.; Chiang, W.D.; Lin, W.T. Did the Older Adutls' Physical Health Affect their Behaviors of Eating Food Away from Home in Taiwan? IEEE: New York, NY, USA, 2013; pp. 695-700.

94. Lesakova, D.; Dano, F. Food Shopping Behaviour in Older Consumers' Segment; Oeconomica Publishing House: Prague, Czech Republic, 2016; pp. 270-280.

95. Locher, J.L.; Ritchie, C.S.; Roth, D.L.; Sen, B.; Vickers, K.S.; Vailas, L.I. Food choice among homebound older adults: Motivations and perceived barriers. J. Nutr. Health Aging 2009, 13, 659-664.

96. Lopes, E.L.; Garcia, E.; dos Santos, V.M.; Schiavo, M.A. The new consumer elderly: Analysis of relevant retailer attributes. RAE-Rev. Adm. Empres. 2013, 53, 551-564.

97. Lumbers, M.; Raats, M. Food Choices in Later Life; Cabi Publishing-C a B Int: Wallingford, CT, USA, 2006; pp. $289-310$.

98. Madgwick, D.; Ravenscroft, N. What's local? Access to fresh food for older people. Local Econ. 2011, 26, 108-121.

99. Mason, J.B.; Bearden, W.O. Satisfaction-dissatisfaction with food shopping among elderly consumers. J. Consum. Aff. 1979, 13, 359-369.

100. Meneely, L.; Burns, A.; Strugnell, C. Food retailers' perceptions of older consumers in Northern Ireland. Int. J. Consum. Stud. 2008, 32, 341-348.

101. Meneely, L.; Burns, A.; Strugnell, C. Age associated changes in older consumers retail behaviour. Int. J. Retail. Distrib. Manag. 2009, 37, 1041-1056.

102. Meneely, L.; Strugnell, C.; Burns, A. Elderly consumers and their food store experiences. J. Retail. Consum. Serv. 2009, 16, 458-465.

103. Mingioni, M.; Mehinagic, E.; Laguna, L.; Sarkar, A.; Pirttijarvi, T.; Van Wymelbeke, V.; Artigas, G.; Chen, J.; Kautola, H.; Jarvenpaa, E.; et al. Fruit and vegetables liking among European elderly according to food preferences, attitudes towards food and dependency. Food Qual. Prefer. 2016, 50, 27-37.

104. Munoz-Plaza, C.E.; Morland, K.B.; Pierre, J.A.; Spark, A.; Filomena, S.E.; Noyes, P. Navigating the Urban Food Environment: Challenges and Resilience of Community-dwelling Older Adults. J. Nutr. Educ. Behav. 2013, 45, 322-331.

105. Nakamura, H.; Nakamura, M.; Okada, E.; Ojima, T.; Kondo, K. Association of food access and neighbor relationships with diet and underweight among community-dwelling older Japanese. J. Epidemiol. 2017, 27, 546-551.

106. Naughton, P.; McCarthy, S.N.; McCarthy, M.B. The creation of a healthy eating motivation score and its association with food choice and physical activity in a cross sectional sample of Irish adults. Int. J. Behav. Nutr. Phys. Act. 2015, 12, 10.

107. Oeser, G.; Aygun, T.; Balan, C.L.; Corsten, T.; Dechene, C.; Ibald, R.; Paffrath, R.; Schuckel, M.T. Implications of the ageing population for the food demand chain in Germany. Int. J. Retail. Distrib. Manag. 2018, 46, 163-193.

108. Oeser, G.; Aygun, T.; Balan, C.L.; Paffrath, R.; Schuckel, M.T. Segmenting elder German grocery shoppers based on shopping motivations. Int. J. Retail. Distrib. Manag. 2019, 47, 129-156.

109. Omar, M.; Tjandra, N.C.; Ensor, J. Retailing to the "grey pound": Understanding the food shopping habits and preferences of consumers over 50 in Scotland. J. Retail. Consum. Serv. 2014, 21, 753-763.

110. Patel, S.; Dsouza, S.A. Indian elderly women's experiences of food procurement and preparation. J. Women Aging 2019, 31, 213-230.

111. Pavlic, I.; Vojvodic, K.; Puh, B. Segmenting the baby boomer generation: An example of croatian consumers. Ekon. Vjesn. 2018, 31, 47-63.

112. Payette, H.; Shatenstein, B. Determinants of healthy eating in community-dwelling elderly people. Can. J. Public Health Rev. Can. Sante Publ. 2005, 96, S27-S31.

113. Pettigrew, S.; Worrall, C.; Biagioni, N.; Talati, Z.; Jongenelis, M. The role of food shopping in later life. Appetite 2017, 111, 71-78.

114. Peura-Kapanen, L.; Jallinoja, P.; Kaarakainen, M. Acceptability of Convenience Food among Older People. SAGE Open 2017, 7, 11.

115. Quevedo-Silva, F.; Lima, D.D.; Fagundes, M.B.B. Dimensions of food choice process of older consumers in Brazil. Br. Food J. 2018, 120, 984-998.

116. Ravoniarison, A. Senior consumers and risk/benefit trade-off in functional foods. Br. Food J. 2017, 119, $1232-1246$.

117. Rousseau, G. The impact of longevity on older consumer needs: Implications for business. J. Consum. Sci. 2018, 46, 19-33.

118. Rozin, P. Acquisition of food preferences and attitudes to food. Int. J. Obes. 1980, 4, 356-363.

119. Santos, D.M.; Oliveira, B.; Rodrigues, S.S.P.; De Almeida, M.D.V. Effect of sociodemographic variables and time on food group contribution to total food availability in Portuguese elderly households. J. Nutr. Health Aging 2014, 18, 471-478.

120. Santos, D.M.; Rodrigues, S.S.P.; De Oliveira, B.; De Almeida, M.D.V. Diet quality in elderly portuguese households. J. Nutr. Health Aging 2014, 18, 243-250.

121. Schmid, A.; Gille, D.; Piccinali, P.; Butikofer, U.; Chollet, M.; Altintzoglou, T.; Honkanen, P.; Walther, B.; Stoffers, H. Factors predicting meat and meat products consumption among middle-aged and elderly people: Evidence from a consumer survey in Switzerland. Food Nutr. Res. 2017, 61, 11.

122. Schwartz, C.; Vandenberghe-Descamps, M.; Sulmont-Rosse, C.; Tournier, C.; Feron, G. Behavioral and physiological determinants of food choice and consumption at sensitive periods of the life span, a focus on infants and elderly. Innov. Food Sci. Emerg. Technol. 2018, 46, 91-106.

123. Shanks, C.B.; Haack, S.; Tarabochia, D.; Bates, K.; Christenson, L. Factors Influencing Food Choices among Older Adults in the Rural Western USA. J. Community Health 2017, 42, 511-521.

124. Sharkey, J.R.; Johnson, C.M.; Dean, W.R. Food Access and Perceptions of the Community and Household Food Environment as Correlates of Fruit and Vegetable Intake among Rural Seniors. BMC Geriatr. 2010, 10, 12. 
125. Sherman, E.M.; Brittan, M.R. Contemporary food gatherers-Study of food shopping habits of an elderly urban population. Gerontologist 1973, 13, 358-364.

126. Smith, G.C. Grocery shopping patterns of the ambulatory urban elderly. Environ. Behav. 1991, 23, 86-114.

127. Smith, G.C. The cognition of shopping-centers by the central area and suburban elderly-An analysis of consumer information fields and evaluative criteria. Urban. Geogr. 1992, 13, 142-163.

128. Stevens, D.A.; Grivetti, L.E.; McDonald, R.B. Nutrient intake of urban and rural elderly receiving home-delivered meals. J. Am. Diet. Assoc. 1992, 92, 714-718.

129. Sulmont-Rosse, C.; Moller, P.; Issanchou, S.; Koster, E.P. Effect of Age and Food Novelty on Food Memory. Chemosens. Percept. 2008, 1, 199-209.

130. Swida, J.; Halagarda, M.; Popek, S. Perceptions of older consumers regarding food packaging as a prerequisite for its improvement: A case study of Polish market. Int. J. Consum. Stud. 2018, 42, 358-366.

131. Tantiwong, D.; Wilton, P.C. Understanding food store preferences among the elderly using hybrid conjoint-measurement models. J. Retail. 1985, 61, 35-64.

132. Teerakapibal, S.; Melanthiou, Y. The new helping the old Social media as a facilitator for variety seeking in food choices of the grey population. Br. Food J. 2019, 122, 272-290.

133. Teller, C.; Gittenberger, E.; Schnedlitz, P. Cognitive age and grocery-store patronage by elderly shoppers. J. Market. Manag. 2013, 29, 317-337.

134. Thompson, J.L.; Bentley, G.; Davis, M.; Coulson, J.; Stathi, A.; Fox, K.R. Food shopping habits, physical activity and health-related indicators among adults aged $\geq 70$ years. Public Health Nutr. 2011, 14, 1640-1649.

135. Thong, N.T.; Solgaard, H.S. Consumer's food motives and seafood consumption. Food. Qual. Prefer. 2017, 56, 181-188.

136. Tongren, H.N. Determinant behavior characteristics of older consumers. J. Consum. Aff. 1988, 22, $136-157$.

137. van der Meij, B.S.; Wijnhoven, H.A.H.; Finlayson, G.S.; Oosten, B.S.H.; Visser, M. Specific food preferences of older adults with a poor appetite. A forced-choice test conducted in various care settings. Appetite 2015, 90, 168-175.

138. van der Zanden, L.D.T.; van Kleef, E.; de Wijk, R.A.; van Trijp, H.C.M. Understanding heterogeneity among elderly consumers: An evaluation of segmentation approaches in the functional food market. Nutr. Res. Rev. 2014, 27, 159-171.

139. van der Zanden, L.D.T.; van Kleef, E.; de Wijk, R.A.; van Trijp, H.C.M. Knowledge, perceptions and preferences of elderly regarding protein-enriched functional food. Appetite 2014, 80, 16-22.

140. van der Zanden, L.D.T.; van Kleef, E.; de Wijk, R.A.; van Trijp, H.C.M. Examining heterogeneity in elderly consumers' acceptance of carriers for protein-enriched food: A segmentation study. Food. Qual. Prefer. 2015, 42, 130-138.

141. van der Zanden, L.D.T.; van Trijp, H.C.M. Designing New and Functional Foods for the Aging. In Food for the Aging Population, 2nd ed.; Raats, M.M., DeGroot, L., VanAsselt, D., Eds.; Woodhead Publ Ltd.: Cambridge, UK, 2017; pp. $323-347$.

142. Venn, S.; Burningham, K.; Christie, I.; Jackson, T. Consumption junkies or sustainable consumers: Considering the grocery shopping practices of those transitioning to retirement. Ageing Soc. 2017, 37, 14-38.

143. Vilar-Compte, M.; Gaitan-Rossi, P.; Perez-Escamilla, R. Food insecurity measurement among older adults: Implications for policy and food security governance. Glob. Food Secur. Agric. Policy 2017, 14, 87-95.

144. Villanueva, M.T.O.; Prieto, A.D.; Gonzalez, M.T.; Abellan, G.B. Consumption habits of apiary products in an elder collective. Arch. Latinoam. Nutr. 2002, 52, 362-367.

145. Walker, T.A.; Lee, J.S. Changes in key food purchasing practices of Supplemental Nutrition Assistance Program (SNAP)-eligible older adults following SNAP benefit receipt. Transl. Behav. Med. 2020, 10, 1286-1296.

146. Worsley, A.; Wang, W.C.; Hunter, W. Baby boomers' food shopping habits. Relationships with demographics and personal values. Appetite 2010, 55, 466-472.

147. Worsley, T.; Wang, W.C.; Hunter, W. Baby boomers' reasons for choosing specific food shops. Int. J. Retail. Distrib. Manag. 2011, $39,867$.

148. Yeung, D.L.; Scythes, C.A.; Zimmerman, S.A.; Pennell, M.D. Nutrition of Canadians 65 Years and over-A review. Can. J. Public Health Rev. Can. Sante Publ. 1986, 77, 363-366.

149. Zalega, T. Consumer and Dietary Behaviour of Polish Silver Singles. Probl. Zarz. 2020, 18, 134-158.

150. Boulet, M.; Hoek, A.C.; Raven, R. Towards a multi-level framework of household food waste and consumer behaviour: Untangling spaghetti soup. Appetite 2021, 156, 104856. 